Mirela Panait ${ }^{1}$ Gabriel Petrescu Marius ${ }^{2}$
JEL: L15, Q01, M14

DOI: 10.5937/industrija43-8981

UDC: 005.62

005.35

502.131.1

Professional Paper

\title{
Quality Management and Social Responsibility in the Context of Sustainable Development
}

\author{
Article history: \\ Received: 2 September 2015 \\ Sent for revision: 6 October 2015 \\ Received in revised form: 17 November 2015 \\ Accepted: 26 November 2015 \\ Available online: 30 December 2015
}

\begin{abstract}
The authors have analyzed two major determinants of sustainable development: quality management and social responsibility. The sustainable development is a concept used not only by researchers in domains like economics or ecology, but also by managers of different types of organizations that try to transpose this concept in real life. Many organizations like corporations, public institutions or small and medium enterprises promote the goals of sustainable development in their activity through various instruments like social responsibility's programs or the use of different standards. So, the aim of this article is to analyze the relationship between quality management, social responsibility and sustainable development.
\end{abstract}

Keywords: quality management, social responsibility, sustainable development, standards.

\section{Upravljanje kvalitetom i društvena odgovornost u kontekstu održivog razvoja}

Apstrakt: Autori su analizirali dve velike determinante održivog razvoja: upravljanje kvalitetom i društvenu odgovornost. Koncept održivog razvoja ne koriste samo straživači u oblastima kao što su ekonomija ili ekologija, već $i$ rukovodioci različitih organizacija koji pokušavaju da prenesu ovaj koncept u stvarni život. Mnoge organizacije kao što su korporacije, javne institucije ili mala i srednja preduzeća promovišu ciljeve održivog razvoja u svojim

\footnotetext{
${ }^{1}$ Petroleum-Gas University of Ploiesti, Prahova, Romania, email: mirepanait@gmail.com

${ }^{2}$ Petroleum-Gas University of Ploiesti, Prahova, Romania
} 
Panait M., Petrescu Marius G.: Quality Management and Social Responsibility in the...

aktivnostima kroz različite instrumente, kao što su programi društvene odgovornosti ili korišćenje različitih standarda.

Ključne reči: upravljanje kvalitetom, društvena odgovornost, održivi razvoj, standardi.

\section{Introduction}

The continued growth of the world population, phenomenon manifested concomitant with improvement of social organization and development of the world economy - particularly in the sectors like manufacturing and mechanized transport - has led to increased efforts of humankind in order to dominate nature and snatch resources with many effects, often negative, on the environment.

Until recently, the renewable natural resources of the Earth proved to be sufficient for the needs of humanity, but at present, due to the population explosion and the unprecedented development of all economic sectors, the need for raw materials and energy for the production of goods has increased, and long and the intensive use of land resources reveals more obviously an ecological imbalance (Nae 2009). In addition to the beneficial effects that industrialization has had on human evolution, the negative effects have emerged and materialized on environment and human health (fig. 1).

Fig. 1 Consequences of industrial development

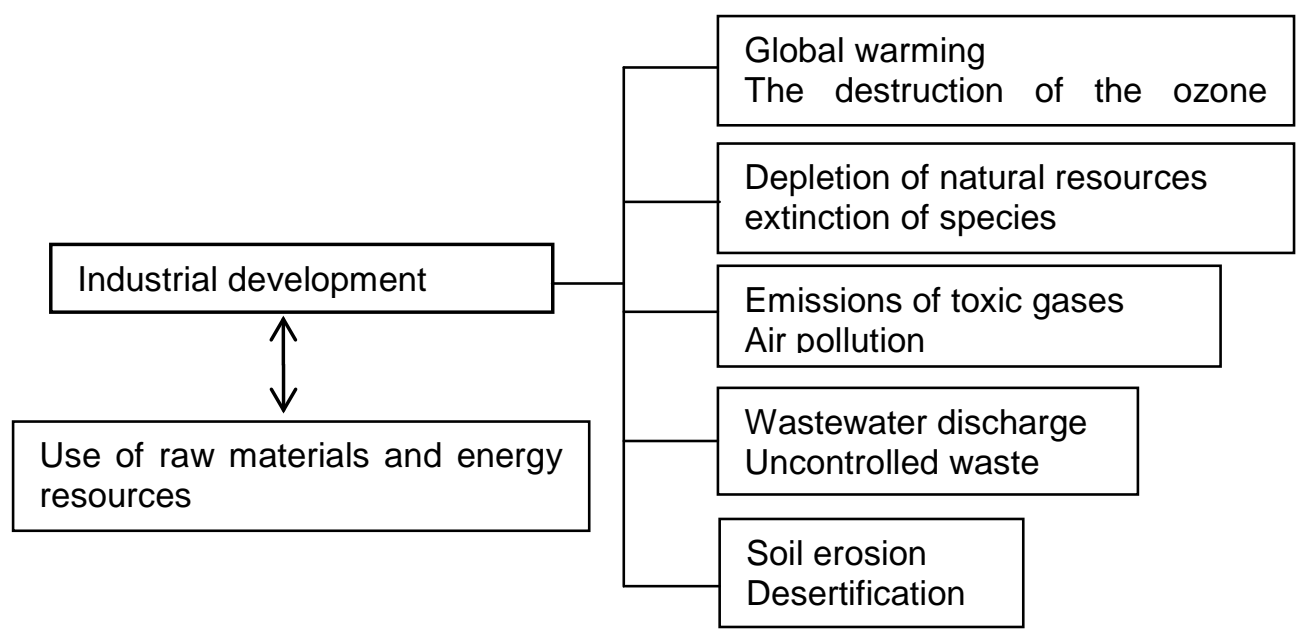


Panait M., Petrescu Marius G.: Quality Management and Social Responsibility in the...

The issues concerning environmental protection are very complex and focus on economic, social and political matters. Solving these problems imposes the participation of all parties involved in monitoring environmental factors: private and public companies, consumers, public authorities, universities, portfolio investors, financial institutions, associations interested in environmental protection.

As a result of the afore mentioned issues, the society, especially concerned with aspects regarding quality of products, became increasingly interested in environmental issues. We note the organization of the Conference on the Human Environment in Stockholm, in 1972. This conference marked the outbreak of the United Nations Environment Program because it drew attention to the negative ecological phenomena such as acid rain or greenhouse effects. Gradually, politicians and businessmen became aware of the need to integrate environmental and socio-economic development in their actions and strategies. The international meetings like United Nations Conference on Environment and Development from 1992 (called Rio Conference or Earth Summit), 2009 United Nations Climate Change Conference (known as the Copenhagen Summit) and United Nations Conference on Sustainable Development (known as Rio 2012 or Rio+20) are aimed at finding the tools to equilibrate economic, social and environmental goals.

Nowadays, "organizations of all kinds are increasingly concerned to achieve and demonstrate sound environmental performance by controlling the impacts of their activities, products and services on the environment, taking into account their environmental policy and objectives. They do so in the context of increasingly stringent legislation, the development of economic and other measures to foster environmental protection, and a general growth of concern from interested parties about environmental matters and sustainable development." (SR EN ISO 14000).

The ecological crisis caused by intense industrial exploitation of resources and environmental degradation have determined the occurrence and development of concepts like sustainable development or social responsibility. In the first phase, the main preoccupation was environmental quality and protection of nature. Taking in account the interdependence between economic and social domains, the concept of sustainable development is focused on quality of life in its complexity too, and takes into account economic and social aspects. (Ionescu 2003).

Consequently, the sustainable development has interferences with other concepts like quality management, environmental management and social responsibility. The companies and the public authorities must focus not so much on the economic performances, with any risk, but on ensuring performance in the context of sustainable development, taking into account 
Panait M., Petrescu Marius G.: Quality Management and Social Responsibility in the...

the economic, social and governance (ESG) aspects. For these reasons, many companies approach environmental management and social responsibility that are considered as essential requirements for sustainable development. Protection of the environment is a purpose even for portfolio investors, stock exchanges, universities and financial institutions.

\section{Quality management - promoter of sustainable development}

Quality management represents assembly of coordinated activities that align and keep under control an organization with regard to quality. These activities include: quality planning, quality controlling, quality assurance and quality improvement (Olaru et al. 2005; Dzopalic et al. 2010 ).

Quality management systems that are conceptually based on ISO 9000 family of standards enable an organization to identify strengths and weaknesses, including provisions for evaluation against generic models, which facilitates continuous improvement - PDCA cycle (Tab. 1). In addition, the models of excellence have emerged requiring development with particular emphasis on quality management functions.

The strategic planning of company's growth and the improvement of competitive goals of sustainable development ensure the satisfaction of all stakeholders by expanding objectives and balancing organizational resources allocated for this purpose. In this context, the whole set of quality management tools is a useful instrument for achieving the permanent goals of sustainable development.

Philosophy on quality and the concept of quality activities changed at the time when the switch was made from the concept of quality control to the concept of product quality assurance. More specifically, it was at the time of changed focus from product to customers, from corrective action to preventive and predictive actions, from centralized management to leadership, from individual work to teamwork, the intervention jumps on equipment and processes to TPM-type activities (Total Productive Maintenance), from quality standards imposed to suppliers by powerful organizations to models and internationally recognized standards (Petrescu 2006, Nae 2009).

Today, all these requirements have become major preoccupations of managers, who are faced with their own interpretation of these documents so that the organizations would ensure sustainable development. 
Panait M., Petrescu Marius G.: Quality Management and Social Responsibility in the...

Sustainable development refers to the forms and methods of implementation of socio-economic growth, aimed at ensuring the balance between the socioeconomic systems and elements of nature and the environment.

We remark behavioral development of managers. This trend is driven by rapid changes in the regulations regarding quality of environmental factors, the new evolutions on the international market (globalization, regionalization, the implication of stakeholders in the activity of companies), and the existence of a different value system in the industrial sector. In the coming years, this trend will intensify, because the specialists consider that the environment is a primary factor of production, being on the same level of importance like human resources and capital, etc.

Table 1. The main aspects of PDCA cycle

\begin{tabular}{|l|l|}
\hline Aspect & Content \\
\hline PLAN (P) & $\begin{array}{l}\text { Establish objectives and determine the processes needed for making } \\
\text { products according to customer requirements in line with the } \\
\text { organization's policy. } \\
\text { Assessing the processes that contribute to product quality planning is } \\
\text { the first step and is followed by resettling of action plans that lead to } \\
\text { continuous improvement of processes and thus achieve the objectives. }\end{array}$ \\
$\begin{array}{l}\text { Feedback from the customer can lead to modifications and / or } \\
\text { planning or new business processes and the communication process } \\
\text { contributes to the success of the planned action. }\end{array}$ \\
$\begin{array}{l}\text { The planned actions are supported by the establishment of working } \\
\text { methods, identification of necessary training of personnel involved, } \\
\text { identification and implementation of legal and regulatory requirements, } \\
\text { work procedures, process diagrams / flow of activities, quality plans, } \\
\text { and production documentation of the goods. }\end{array}$ \\
\hline DO (D) & $\begin{array}{l}\text { The actions are implemented according to established plans with } \\
\text { consideration of proposals on melioration of the quality management } \\
\text { system, process design, performance improvement, teamwork, } \\
\text { communication process, etc. }\end{array}$ \\
\hline CHECK & $\begin{array}{l}\text { The actions regarding the measurement and monitoring of products } \\
\text { and processes set out in the planning phase are implemented and the } \\
\text { results are reported. The QMS audits and performance indicators } \\
\text { established constitute the main instruments for checking. }\end{array}$ \\
\hline ACT (A) & $\begin{array}{l}\text { In this phase, actions (for continuous performance improvement } \\
\text { processes taking into account: documenting and implementing } \\
\text { processes / activities, analyzing and updating performance criteria and } \\
\text { other criteria - acceptance, rejection etc.- training of staff at all levels, } \\
\text { evaluation of results, initiating corrective / preventive actions resulting } \\
\text { from the political, quality objectives, internal and external audits, } \\
\text { management reviews, which can generate or process changes in } \\
\text { organization development) are implemented. }\end{array}$ \\
\hline
\end{tabular}

Source Bucuroiu 2014 
Panait M., Petrescu Marius G.: Quality Management and Social Responsibility in the...

At the company level, the environmental protection management must ensure the link between policy, objectives and programs, and the result of its business unit, beyond customer's perception regarding the product, including environmental impacts. The environmental protection management should be considered as a continuation of quality management that extends the enterprise's policy from strict organizational aspects to evaluation of the effects of pollution and quality assessment of monitoring systems (Fig. 2).

Figure 2. Algorithm of sustainable development from management perspective (in the authors' proposal)

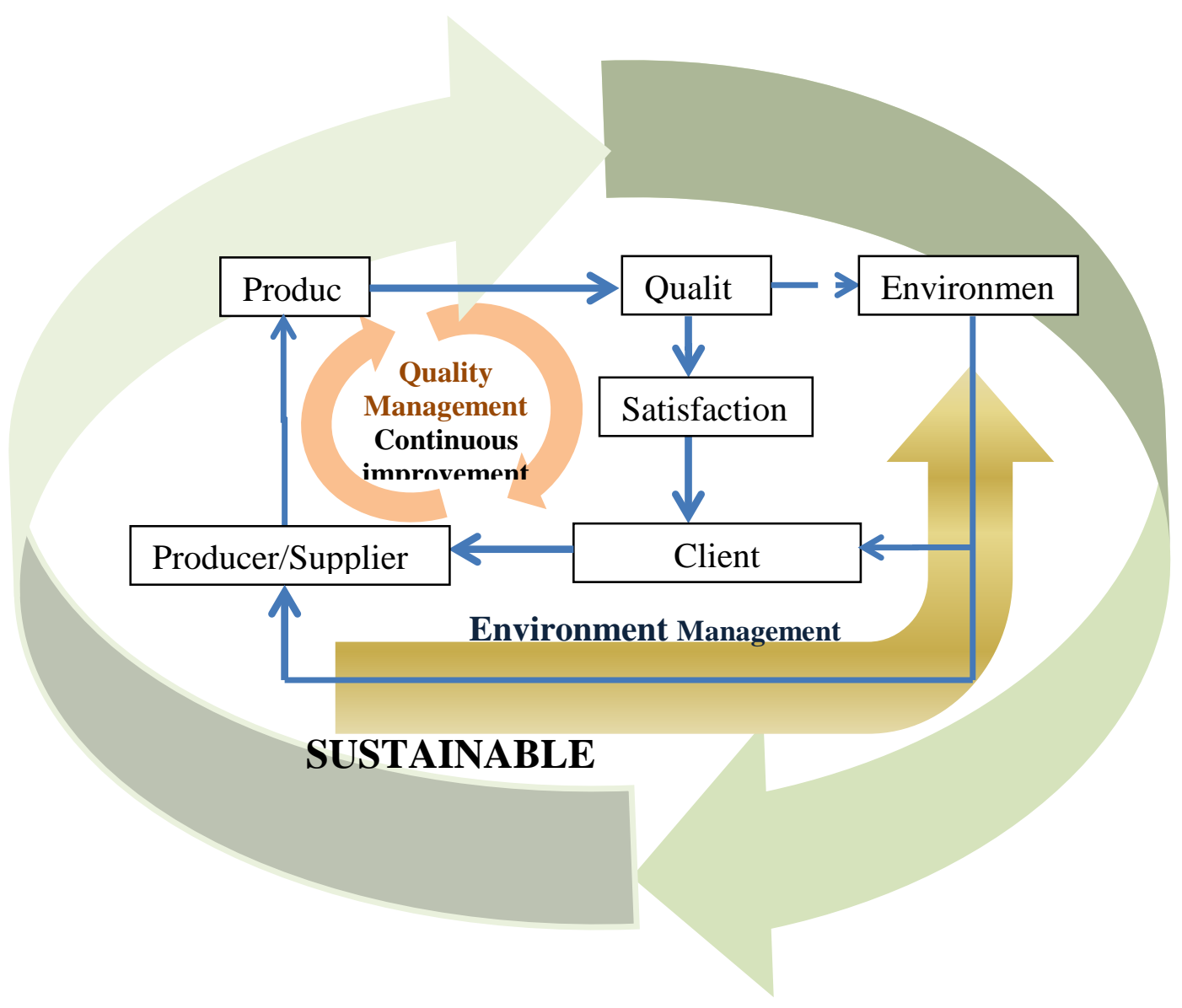


Panait M., Petrescu Marius G.: Quality Management and Social Responsibility in the...

Taking into account the algorithm from Figure 2, we can notice the role of quality management and, in particular, the ongoing improvement in strengthening environmental policy and sustainable development.

In efforts to ensure the sustainable use of resources and compliance of environmental quality regulations, environmental management policy should provide ways to influence decision-making procedures at the microeconomic level for conditioning the impact on product quality environment.

The companies and, equally, the customers must perceive and accept the quality beyond the moment of satisfaction, as a result of direct interaction with the product, and they must recognize its continuous interaction with the environment - in the stages of design, use and disposal - guaranteeing, in this way, the long-term satisfaction.

Rational managers and customers will base their decisions on weighing the costs and benefits, and their analysis will take account of: changing the characteristics of the product generating satisfaction; changing priorities concerning the use of the product; modification of the importance for the environment. In such circumstances, the need to ensure sustainable development will transfer from the coercive, restrictive to volunteer rules based on reason and respect for future generations.

\section{Social Responsibility (SR) and Sustainable Development}

Although the concerns of European and international bodies are particularly intense on conceptualization and promoting SR through various instruments such as the development of principles (Global Compact principles established by the United Nations Organization), creating platforms, establishment of nonfinancial reporting rules, the activities regarding social responsibility is not regulated at this time.

At European Union level, the main document targeting this area of social responsibility is Green Paper "Promoting a European Framework for Corporate Social Responsibility". According to European authorities, corporate social responsibility (CSR) is "voluntary decision of the undertaking to contribute to the betterment of society to a cleaner environment." Moreover, "a socially responsible enterprise has to satisfy the legal requirements and comply and invest in human capital, the environment and relations with stakeholders".

For this reason, it is considered a form of self-regulation integrated business model or strategy that seeks potentiation of positive effects of their businesses on environment, consumers, employees and the community in 
Panait M., Petrescu Marius G.: Quality Management and Social Responsibility in the...

general, or as a deliberate pursuit of public interest by companies. The companies must have in mind the three Ps: population; planet and profit, while their activities` performance have three dimensions - social, environmental and financial (triple bottom line). (Elkington 2004).

The three Ps: people, planet and profit or the "three pillars of sustainability" are elements that are essential for evaluation of the performance of different organizations in a broader context. The Triple Bottom Line supposes the incorporation of environmental, social and governance (ESG) aspects in the activity of any company or public institution.

Over time, we can observe reshaping of the state's role in the economy and redefining of the role of public and private sectors in economic development. It became increasingly obvious that businesses, through their voluntary actions should manage the economic, social and environmental impact so as to contribute to the sustainable development of the world economy. Thus the concept of social responsibility develops and aims at the potentiation of the companies positive impact on the environment and local and international community in which they operate. The transnational companies have become the main promoters of the concept, but their complex activities at international level determine other actors like suppliers, customers and even local consumers that can adopt CSR principles in their work. Although the impact of CSR actions undertaken by local enterprises is quite low, we observe a social emancipation of smaller companies in developing countries (Sima\&Gheorghe 2011).

According to the principles of Global Compact promoted by the United Nations, the four areas of social responsibility programs are environment, labor standards, human rights and fight against corruption. Consequently, the concept of CSR has certain interrelated areas with concepts as management, cause related marketing, business ethics, communication and corporate governance. (Maignan\& Ferrell 2004), (Jamali, Safieddine, \& Rabbath 2008).

So far, we have emphasized the voluntary character of social responsibility actions, initiated by company's managers based on a detailed analysis of the costs and risks of the CSR programs and the benefits that may occur: improving the company's image among consumers, especially for companies operating in polluting industries, increase of the market share, sales or profits, improvement of competitive advantage (Porter\& Kramer 2006). The initiation of these programs requires a detailed financial analysis to decide whether implementation of the program is advantageous to the company.

Social responsibility entails a risk management, given the possibility to record potential negative effects or failures even by the originator company. Furthermore, implementation of the social responsibility programs helps 
Panait M., Petrescu Marius G.: Quality Management and Social Responsibility in the...

avoidance of bankruptcy risk, insolvency risk, major layoffs, and the risk of inconsistent behavior against the ethical code of the profession, moral principles and business ethics. Based on this idea, we can differentiate between corporate behavior in normal and critical economic conditions. Therefore, in the current international economic crisis, there are cases of inadequate actions in some companies that, for the purpose of maintaining their profit or their market position, violate human rights, generate or encourage corruption or do not have a friendly attitude toward the environment. (Matei 2013).

Communication plays an important role because it can improve the company's image among consumers, employees and businesses. In this regard, the advertising at the launching and completion of such programs is essential for transmitting positive signals regarding company's involvement in promoting the sustainable development principles. In case of larger companies and those listed on major stock exchanges, annual reports on social responsibility provide better information to the public.

Social responsibility is not the exclusive prerogative of companies. For this reason, at international level, the Global Compact developed the Principles for Responsible Management Education - PRME. In this way, a framework was created for promoting social responsibility in universities by incorporating the universal values of social responsibility into curricula and research activity. According to these principles, the universities will develop the capabilities of students to be future generators of sustainable value for business and society in general, and to work in a global sustainable economy. In addition, the universities will interact with corporate managers in order to expand the knowledge on specific challenges of social responsibility and on studying the approaches necessary for addressing these challenges. Universities will facilitate and support dialog and debate among teachers, students, public institutions, consumes, media, civil society's organizations and other stakeholders on critical issues regarding social responsibility and sustainability. The importance of the role of universities in promoting social responsibility is confirmed by a specialized educational institution Responsible Investment Academy set up by the Australian government. This university collaborates with the Secretariat of PRI (Principles for Responsible Investment) to support institutional investors that signed the Principles for Responsible Investment. The courses offered by this institution of higher education focus on the following issues: implementation of the Principles Responsible Investment, integration of ESG (environmental, social and governance) aspects on analysis of securities and construction portfolios, engagement of investors as shareholders and voting policies, sustainable development, changes of climate and low-carbon economy transition, human rights, employment, water and energy security. 
Panait M., Petrescu Marius G.: Quality Management and Social Responsibility in the...

Cities and local authorities have significant influences on the environment, but also on companies and citizens who operate or live in their operating range. For these reasons, the cities can influence the activity of many stakeholders in these issues: labor standards, human rights, environment and the fight against corruption, which are actually the four international guidelines promoted by the Global Compact Principles for cities.

At international level, we observe a wide range of instruments and structures that promote social responsibility:

$>$ laws and regulations (e.g. international labor law),

$>$ strategies and action plans regarding social responsibility or sustainable development (like national strategies on sustainable development in EU countries or EU strategy for promotion CSR Communication from the Commission concerning CSR: A business contribution to sustainable development no347/2002)

> standards and guidelines established by international entities (e.g. ISO 14000 series, ISO 26000, Global Reporting Initiatives - GRI, OECD Guidelines)

> principles (e.g. UN Global Compact) set up at international level;

$>$ policies and strategies at individual company and industry level (e.g. code of conduct in sugar industry or electronic industry)

$>$ regulations imposed by financial organizations (Ecuator Principles, Guidelines or principles for CSR established by stock exchanges.

Taking into account the efforts made by United Nations Global Compact to set up and promote principles for social responsibility for different types of entities, we consider that social responsibility is a concept applicable to all type of organizations like transnational corporations, small and medium enterprises, universities, public authorities, portfolio investors, stock exchanges.

At the first sight, social responsibility is a very widespread and complex concept, and many specialists (Hahn 2012) consider that topic unsuitable for standardization taking into account the issues covered by it (from the environment to fight against corruption and respect of human rights) and the characteristics depending on type or organizations and industry.

We notice that until 1980s, the "quality management" and "environmental management" shared the same status. In time, the efforts made by International Organization for Standardization to promote standards for these issues (ISO 9001 for quality management and ISO 14001 for environmental management) paid off and these standards are amongst the most well-known and widely implemented standards at international level. 
Panait M., Petrescu Marius G.: Quality Management and Social Responsibility in the...

Taking into account this consideration, we remark the effort made by International Organization for Standardization - ISO that promotes ISO 26000:2010. This standard is a tool useful for organization in order to increase their contribution to sustainable development. This standard is complementary with other tools and initiatives existing at international level on this topic. The most important characteristic of this standard is that it is not a management system standard. Even though it does not contain requirements and, as such, cannot be used for certification, it has an important practical value because the organizations are able to understand the concept of social responsibility and facilitate the management routines and practices.

Figure 3. Social responsibility: core subjects

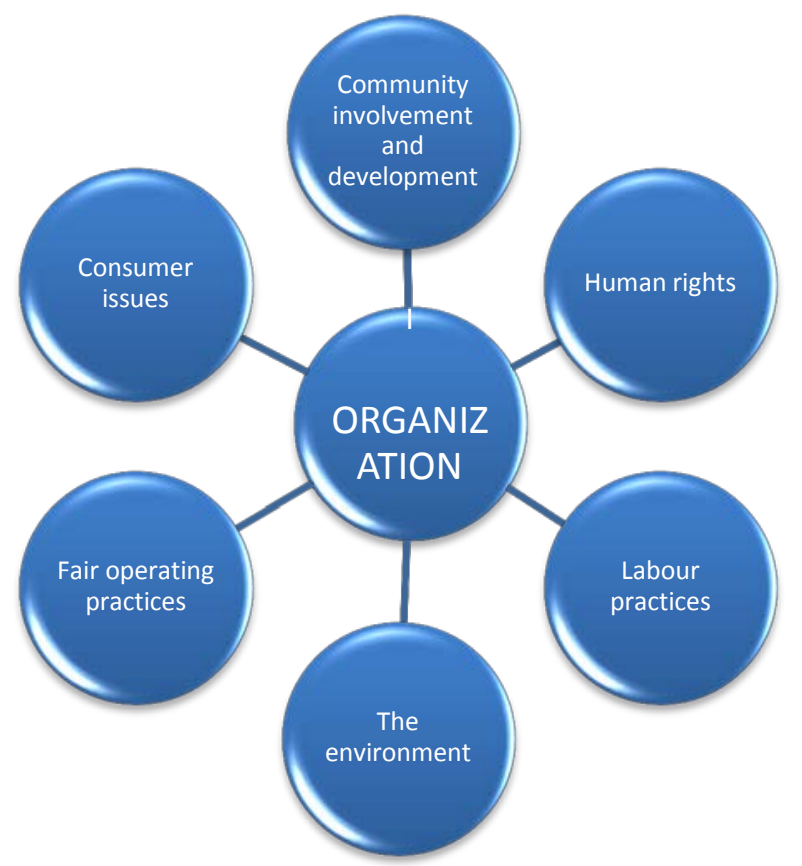

Source: http://www.iso.org/iso/discovering_iso_26000.pdf

Social Responsibility ("SR") of an organization is defined by the International Organization for Standardization ("ISO") in ISO 26000 "Guidance on Social Responsibility", published in November 2010 (pp. 3-4) as: "responsibility of an organization for the impacts of its decisions and activities on society and the environment, through transparent and ethical behavior that - contributes to sustainable development, including health and the welfare of society; - takes 
Panait M., Petrescu Marius G.: Quality Management and Social Responsibility in the...

into account the expectations of individuals or groups that have an interest in any decision or activity of the organization (stakeholders); - is in compliance with the applicable law and consistent with international norms of behavior; and - is integrated throughout the organization and practiced in its relationships".

This standard has seven clauses regarding the following items: scope; terms and definitions; understanding social responsibility, principles of social responsibility, recognizing social responsibility and engaging stakeholders, guidance on social responsibility core subjects, guidance on integrating social responsibility throughout an organization.

ISO 26000 sets guiding principles of social responsibility. These are: accountability, transparency, ethical behavior, respect for stakeholder's interest, respect for the rule of law, respect for international norms of behavior and respect for human rights. So, ISO 26000 is important for organizations of all types because provides guidance on the integration of social responsibility into management processes.

In the field of social responsibility, we notice also the activity of Global Reporting Initiative (GRI), an international association that launched the concept of 'triple bottom line'. This association encourages the companies to shift from the traditional reporting to a complex one that includes social environmental and economic issues (Hedberg\&von Malmborg, 2003). It is important for the stakeholders to be informed about the impact of the company's activities on critical sustainability issues such as human rights, corruption and impact on the environment. In order to help the different types of organizations to improve the communications with their stakeholders, GRI launchGRI's Sustainability Reporting Standards that are used in over 90 countries.

\section{Conclusions}

Standardized management systems like ISO 14001 and ISO 9001 are used in many organizations and they are the most known standards at international level. Taking into account their advantages for companies (mentioned in particular in the literature by Richard Reed, David J. Lemak, Neal P. Mero, 2000) - saved time, increase of product quality, sales and revenues, reduction of costs, generation of competitive advantages - there are new standards with elements regarding environment, business ethics and social responsibility ISO 26000, Social Accountability 8000 (SA 8000) and AccountAbility 1000 (AA1000:2000). 
Panait M., Petrescu Marius G.: Quality Management and Social Responsibility in the...

Sustainable development is a concern for various types of stakeholders like: companies, public authorities, international organizations, citizens. Each one of them has its own driver that may be moral, legal, political or commercial one. Irrespective of motivation, the result is what matters: the improvement of organizations " performance in terms of sustainability.

Modern management focuses primarily on the market in terms of ensuring the permanent customer's satisfaction. Continuity of such action is facilitated by applying the principle of continuous improvement with four phases of PDCA cycle. Lately, managers have been addressing environmental and social issues, most frequently under the influence or restrictions imposed by legislation or stakeholders. So, SR has strategic, altruistic or coercive motivations.

Given the goals of sustainable development, we believe that managers should be the promoters of inclusion, unconditional (without posing effect of restrictive laws) in the concept of product quality of environmental, social and governance (ESG) issues.

Similarly, the client must achieve a superior level of culture, characterized by accepting a new quality of products capable of providing satisfaction and proving to be equally "environmentally and socially friendly".

At international and national level, there are many SR-related codes of conduct, guidelines, initiatives and principles. The field of SR is considered embryonic because of the lack of a globally acceptable "standard". Taking into account the global dominance of quality and environmental management systems standards - ISO 9000 and ISO 14000, International Organization for Standardization (ISO) is providing a new standard for social responsibility called ISO 26000 . The degree of diffusion of this standard depends on many factors like implication of government, the position of SR proactive countries like Great Britain and the Netherlands

For organizations, it is important to make their operations sustainable but also to disclosure accessible and comparable information and to measure the impacts of their activities on social, environment and economic domains. GRI Sustainability Reporting Guidelines provide useful instruments for any type of organization for preparing a sustainability report.

\section{References}

Bucuroiu, R. (2014). Cercetări privind implementarea și dezvoltarea unui sistem integrat de management cu aplicare la fabricarea și/sau repararea sculelor pentru sondele de petrol și gaze. Ploiești. 
Panait M., Petrescu Marius G.: Quality Management and Social Responsibility in the...

Dzopalic, M., Zubovic, J., \& Bradic-Martinovic, A. (2010). Effective implementation of e-CRM strategy. Polish Journal of Management Studies, 54-65. Retrieved from http://yadda.icm.edu.pl/yadda/element/bwmeta1.element.baztech-article-BPC80006-0022

Elkington, J. (2004). Enter the triple bottom line. The triple bottom line: Does it all add up, 11(12), 1-16. Retrieved from http://kmhassociates.ca/resources/1/Triple\%20Bottom\%20Line\%20a\%20history \%201961-2001.pdf

Hahn, R. (2012). Standardizing social responsibility?, New perspectives on guidance documents and management system standards for sustainable development. IEEE - Transactions on Engineering Management, 59(4), 717-727. $11 . \quad$ Retrieved from http://ieeexplore.ieee.org/xpl/articleDetails.jsp?arnumber=6166876 doi:10.1109/TEM.2012.2183639

Hedberg, C. J., \& Von Malmborg, F. (2003). The global reporting initiative and corporate sustainability reporting in Swedish companies. Corporate social responsibility and environmental management, 10(3), 153-164.

Ionescu, C. (2003). Politici de management de mediu. Bucuresti: UPB. (curs).

Jamali, D., Safieddine, A. M., \& Rabbath, M. (2008). Corporate governance and corporate social responsibility synergies and interrelationships. Corporate Governance: An International Review, 16(5), 443-459. Retrieved from , http://wwwlb.aub.edu.lb/osb/csr/research/Documents/CG_and_CSR_Synergies. pdf

Maignan, I., \& Ferrell, O. C. (2004). Corporate social responsibility and marketing: an integrative framework. Journal of the Academy of Marketing science, 32(1), 319. Retrieved from http://smokenetwork.com/e-businessethicscom/wpcontent/uploads/Corporate-Social-Responsibility-and-Marketing.pdf

Matei, M. (2013). Responsabilitatea sociala a corporatiilor si institutiilor si dezvoltarea durabila a Romaniei. Bucuresti: Editura Expert.

Nae, I., Petrescu, M.G., \& Lupu, F. (2009). Managementul cercetării-dezvoltăriiinovării. București: -ILEX,.

Olaru, M., \& ed., (2005). Fundamentele ştiinţei mărfurilor. Bucureşti: Editura Economică.

Oskarsson, K., \& von Malmborg, F. (2005). Integrated Management Systems as a Corporate Response to Sustainable Development, Corporate Social Responsibility and Environmental Management. , 12, 121-128. Retrieved from http://download.clib.psu.ac.th/datawebclib/e_resource/trial_database/WileyInterS cienceCD/pdf/CSR/CSR 5.pdf doi:10.1002/csr.078

Petrescu, M.G. (2006). Manāgementul sistemelor de producţie. Ploieşti: Editura Universităţii din Ploieşti.

Reeda, R., Lemakb, D.J., \& Mero, N.P. (2000). Total quality management and sustainable competitive advantage. Journal of Quality Management, 5, 5-26. Retrieved from http://hadjarian.com/reghabati/1-s2.0-S1084856800000109main.pdf

Sima, V.I.G., \& Gheorghe, I.G. (2011). Social Responsibilty and SMEs in Romania. Petroleum-Gas University of Ploiesti BULLETIN, Economic Sciences Series, 58(1), 92-100. Retrieved from http://www.upg-bulletinse.ro/archive/2011-1/11.\%20Sima_Gheorghe.pdf 
Panait M., Petrescu Marius G.: Quality Management and Social Responsibility in the...

The official site of Romanian National Agency for Ennvironment Protection. Retrieved from www.anpm.ro

Retrieved from http://www.iso.org/iso/home/standards/iso26000.htm

Retrieved from www.riacademy.org

Retrieved from www.unglobalcompact.org 